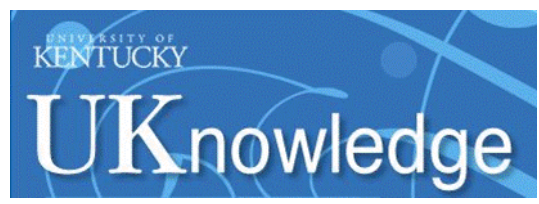

University of Kentucky

UKnowledge Kentucky Injury Prevention and Research Center Kentucky Injury Prevention and Research Center
Faculty Publications

2018

\title{
Missed Work Due to Occupational Illness Among Hispanic Horse Workers
}

Ashley M. Bush

University of Kentucky, ashleybush@uky.edu

Susan C. Westneat

University of Kentucky, swest1@email.uky.edu

Steven R. Browning

University of Kentucky, srbrown@uky.edu

Jennifer Swanberg

University of Maryland - Baltimore

Follow this and additional works at: https://uknowledge.uky.edu/kiprc_facpub

Part of the Agriculture Commons, and the Public Health Commons

Right click to open a feedback form in a new tab to let us know how this document benefits you.

\section{Repository Citation}

Bush, Ashley M.; Westneat, Susan C.; Browning, Steven R.; and Swanberg, Jennifer, "Missed Work Due to Occupational Illness Among Hispanic Horse Workers" (2018). Kentucky Injury Prevention and Research Center Faculty Publications. 3.

https://uknowledge.uky.edu/kiprc_facpub/3

This Article is brought to you for free and open access by the Kentucky Injury Prevention and Research Center at UKnowledge. It has been accepted for inclusion in Kentucky Injury Prevention and Research Center Faculty Publications by an authorized administrator of UKnowledge. For more information, please contact UKnowledge@lsv.uky.edu. 


\section{Missed Work Due to Occupational Illness Among Hispanic Horse Workers \\ Digital Object Identifier (DOI)}

https://doi.org/10.13031/jash.12735

\section{Notes/Citation Information}

Published in Journal of Agricultural Safety and Health, v. 24, issue 2, p. 89-107.

(c) 2018 ASABE

The copyright holder has granted the permission for posting the article here. 


\title{
Missed Work Due to Occupational Illness among Hispanic Horse Workers
}

\author{
A. M. Bush, S. Westneat, S. R. Browning, J. Swanberg
}

ABSTRACT. Occupational illnesses are inadequately reported for agriculture, an industry dominated by a vulnerable Hispanic population and high fatal and nonfatal injury rates. Work-related illnesses can contribute to missed work, caused by a combination of personal and work factors, with costs to the individual, employer, and society. To better understand agricultural occupational illnesses, 225 Hispanic horse workers were interviewed via community-based convenience sampling. Descriptive statistics, bivariate analyses, and log binomial regression modeling were used to: (1) describe the prevalence of missed work due to work-related illnesses among Hispanic horse workers, (2) examine work-related and personal factors associated with missed work, and (3) identify health symptoms and work-related characteristics potentially associated with missed work. Key findings reveal that having at least one child $(P R=1.71,95 \% C I=$ $1.03,2.84)$, having poor self-reported general health $(P R=0.72,95 \% C I=0.48,1.08)$, experiencing stress during a typical workday $(P R=2.58,95 \% C I=1.25,5.32)$, or spending less time with horses $(P R=1.87,95 \% C I=1.15,3.05)$ are significant predictors of missing work. Interventions can be designed to identify workers most susceptible to missing work and provide resources to reduce absenteeism. Future research should examine work-related illness in agricultural horse production, including personal and work-related factors, in order to diminish occupational health disparities among these workers, who are more likely to be employed in hazardous agricultural work.

Keywords. Agriculture, Health disparities, Horse workers, Missed work, Occupational illness, Worker absenteeism.

A gricultural workers suffer elevated nonfatal occupational illness rates, with an even higher rate for the animal production subsector (BLS, 2015a). Severe occupational illnesses may result in workers missing work to recuperate to the extent they can perform their work tasks. Missed work time, an indicator of illness severity (BLS, 2015b), may affect the worker, employer, and society through reduced productivity and business efficiency, medical care, and other indirect costs (Krause et al., 2001). Moreover, the reported work-related illness data likely underestimate the magnitude of the burden (NIOSH, 2012; May, 2009; USHR, 2008; Rosenman et al., 2006; Strong and

Submitted for review in March 2018 as manuscript number JASH 12735; approved for publication by the Ergonomics, Safety, \& Health Community of ASABE in April 2018.

The authors are Ashley M. Bush, Data Management Specialist, Kentucky Injury Prevention and Research Center, Susan Westneat, Epidemiologist, Central Appalachian Regional Education and Research Center, and Steven R. Browning, Associate Professor, Department of Epidemiology, University of Kentucky College of Public Health, Lexington, Kentucky; Jennifer Swanberg, Professor, School of Social Work, University of Maryland, Baltimore, Maryland. Corresponding author: Ashley M. Bush, Kentucky Injury Prevention and Research Center, Lexington, KY 40504; phone: 859-323-9675; e-mail: ashleybush@uky.edu.

Journal of Agricultural Safety and Health

24(2): $89-107 \quad$ C 2018 ASABE ISSN 1074-7583 https://doi.org/10.13031/jash. 12735 
Zimmerman, 2005; Hansen and Donohoe, 2003), especially among Hispanic workers (Strong and Zimmerman, 2005), who make up a large portion of the agriculture workforce (Orrenius and Zavodny, 2009). Although much agricultural health and safety research focuses on the dominant majority (i.e., seasonal and temporary crop workers), the agriculture industry consists of both crop workers and animal workers, the latter often being permanent full-time workers with specialized job skills. Variations within agricultural production regarding farmworker demographics, employment characteristics, farming practices, injuries, and exposures to hazards should be addressed (Arcury and Marín, 2009; May, 2009; Reed, 2004; Stoecklin-Marois et al., 2011; Swanberg et al., 2012). Estimates show that $45 \%$ of the hired agricultural workforce are Hispanic (USDA, 2015), and in the horse production subsector, which involves housing, grazing, breeding, and/or feeding of animals (BLS, 2016), Latinos compose $66 \%$ or more of the workforce (Switzer, personal communication, 21 January 2009; AHC, 2005; the terms "Latino" and "Hispanic" are used interchangeably in this article). In addition to the work hazards that Latino farmworkers encounter, research suggests that they also experience a separate set of risk factors for poor health outcomes due to their culture, language, and minority status that may intensify their occupational health and safety risks (NIOSH, 2012; Culp and Umbarger, 2004; Steege et al., 2009).

Work in the thoroughbred horse industry, which includes the sale, boarding, racing, and breeding of thoroughbred horses (Swanberg et al., 2013), poses unique risks. The strength and quick temperament of thoroughbreds places workers at risk of adverse occupational health outcomes. Typical work tasks include live breeding, foaling, grooming, working night watch, raising and training horses, mucking stalls, landscaping, and performing maintenance (DDAF, 2014; Swanberg et al., 2012, 2013). The sparse literature concerning equine worker health reveals that workers are at risk for exposure to toxic chemicals, medicines, respiratory irritants, horse bites, and zoonotic diseases (Swanberg et al., 2012, 2015; Loving, 2009; Langley and Morris, 2009; Mazan et al., 2009; Speed and Andersen, 2008; Iba et al., 2001). In addition, work-related musculoskeletal injuries and acute injuries from animals, machinery, falls, and plants are prevalent (Swanberg et al., 2012, 2013, 2016, 2017; Langley and Morris, 2009; Speed and Andersen, 2008; Iba et al., 2001).

Respiratory illness, a particular concern for horse workers may, occur from exposures to molds, endotoxins, inorganic dusts, pesticides, chemicals, fermenting manure, barn storage mites, bedding material, and horses (Airaksinen, 2006; Culp and Umbarger, 2004; Kirkhorn, 2002; Spurzem et al., 2002). Horse workers have reported symptoms such as asthma, pneumonia, bronchitis, and allergies (Speed and Andersen, 2008). Agriculture has one of the higher incidences for days away from work due to occupational skin disorders (Lushniak, 2003).Work-related skin diseases, particularly contact dermatitis, are due to exposure to chemicals, pesticides, poison oak/ivy, and ragweed (Stocks et al., 2010; McDonald et al., 2006; Culp and Umbarger, 2004; Kirkhorn and Schenker, 2002). Sunburn and fungal infections are also leading skin disorders among farmworkers (May, 2009). Allergic skin diseases and sensitization to horsehair have been observed among horse workers (Tutluoğlu et al., 2002).

Psychological distress is another health-related issue prevalent among Latino farmworkers that may influence work behavior (Grzywacz et al., 2009, 2014), contribute to missed work time, and lower workplace productivity (Goldberg and Steury, 2001). For example, one quarter of Latino farmworkers in North Carolina exhibited high stress lev- 
els (Kim-Godwin et al., 2014). Among Mexican farmworkers in California, 20\% reported at least one mental health disorder (Alderete et al., 2000), and 20\% to $21 \%$ met the case definition for depression (Alderete et al., 1999). In the Midwest (Michigan and Ohio), $39 \%$ of Mexican farmworkers were diagnosed as clinically depressed (Hovey and Magaña, 2002). Meanwhile, $42 \%$ to $52 \%$ of Hispanic farmworkers in North Carolina had clinical depression (Crain et al., 2012; Hiott et al., 2008), 18\% had high anxiety, and 38\% had alcohol dependence (Hiott et al., 2008). Among Hispanic farmworkers who have high rates of depression and anxiety (Grzywacz et al., 2010), depression was associated with disability (e.g., functional impairment) (Mazzoni et al., 2007). The nature of agricultural work (e.g., long work hours and limited/no benefits) has been considered a contributing factor to poor mental health (Grzywacz et al., 2010; Hiott et al., 2008), thereby contributing to worker absenteeism. Poor mental health has been documented among horse care and backstretch horse workers (Castañeda et al., 2010; Schefstad et al., 1999).

Occupational illnesses are a culmination of work and personal life factors that may contribute to workers missing work (Strong and Zimmerman, 2005). There is a dearth of research examining missed work due to work-related illnesses among horse workers. Among agricultural workers, missed work time was the largest cost associated with occupational illnesses and injuries (Rautiainen et al., 2005). Missed work time due to workrelated illness may serve as a proxy for the severity of the illness and/or reflect other contributing factors, such as the worker's ability to take time off, perception of illness, ability to avoid exposure, and commitment to work, as well as the employer's permission for time off, and the employer's ability to cover the missing worker's responsibilities.

To date, the reviewed literature has not examined work-related illnesses resulting in missed work time in agriculture, where benefits are often minimal, work hazards are prevalent, and Latino workers are a large proportion of the workforce. More attention is needed to understand work-related illnesses and missed work time among agricultural subsectors, as the existing research on occupational illness fails to adequately depict the nature and extent of illnesses within the animal production (e.g., horse workers) industry (NIOSH, 2012). To gain further understanding of and the contributing factors for agricultural work-related illnesses among Latino horse workers, this study: (1) describes the prevalence of missed work due to work-related illnesses and other selected characteristics among a sample of Latino horse workers, (2) examines work-related and personal factors associated with missed work due to work-related illnesses, and (3) identifies health symptoms and work-related characteristics potentially associated with missed work among workers who missed work due to work-related illness in the past year.

\section{Methods}

A cross-sectional survey of Latino farmworkers in the thoroughbred horse industry was undertaken from December 2013 to April 2014. The Thoroughbred Worker Safety and Health Study, or Proyecto de Salud y Seguridad del Trabajador Equino, was designed to understand the occupational health and safety issues of Latino thoroughbred farmworkers in the southeastern U.S. (Swanberg et al., 2012). Detailed methods on sampling, survey development, data collection, and cultural relevancy can be found elsewhere (Swanberg et al., 2016).

\section{Sampling}

Community-based purposive convenience sampling was used to recruit worker partic- 
ipants. The study was promoted via study fliers, word of mouth, and a local Spanish radio infomercial. Participants were eligible when they self-identified as Latino or Hispanic, 18 years of age of older, and were currently employed for at least nine months total (consecutive or non-consecutive) of the previous year by a thoroughbred horse farm. Trained promotoras, also known as community health workers, were used to recruit this hard-toaccess population. Before oral consent was obtained, recruited participants were informed about the study, including the procedures, risks, and benefits, orally and through printed material. A total of 225 horse workers participated in this 1 to 1.5 hour survey, which was administered in English or Spanish per the worker's preference. Study methods were approved by the University of Kentucky Institutional Review Board.

\section{Measures}

The primary dependent variable measured whether a worker experienced a workrelated illness in the past 12 months that required time off from work (Myers and Cole, 2008). Workers were asked if they had come to work when they were ill in the past year (yes/no) and why they chose to come to work when ill (open response).

Demographic measures were modified from the National Agricultural Workers Survey, which has been previously used in research with Latino and immigrant worker groups (USDOL, 2005, 2010). Measures included gender, nativity, U.S. residency time, marital status (married/living as married or not married/living as married), spouse residency (with or without worker), and children (at least one). The education measure was modified from the Farmworkers and Visual Impairment Instrument (Arcury, 2009) that classified education as 1-6 years (primaria), 7-9 years (secundaria), 10-12 years (preparatoria, 12th grade or GED), and 16 years (finished college). These education groups were modified to also include 0 years (no school) and some college or more. To complement the Mexican educational system, elementary education (primaria) is considered completed at the sixth grade.

Health-related items, current smoking status (Mazan et al., 2009; Rylander et al., 1990), and health symptoms in the past year (Mazan et al., 2009; Rylander et al., 1990) were coded as binary variables (yes/no). Health symptoms included headache, throat irritation, nasal irritation, dry cough, productive cough, sinus trouble, chest tightness, and wheezing. Workers were asked if these health symptoms improved when they were away from the barn for at least one day; if they ever woke up at night due to wheezing, whistling, coughing, or difficulty breathing; and if any of their health symptoms caused them to miss work or normal activities (Mazan et al., 2009; Rylander et al., 1990). Doctordiagnosed diseases (asthma, skin irritation, and eye irritation) were collected as dichotomous measures (USDOL, 2005, 2010). The validated and reliable general health status measure of Ware et al. (1996) captured workers' self-reported health perceptions using a four-point Likert scale, ranging from excellent to poor, for how workers described their general health.

The depressive symptoms score was a continuous variable measuring the sum of ten items from the CES-D Depression Symptoms Index (Kohout et al., 1993), which is a validated screening tool for depression and depressive disorders among immigrants and Latino farmworkers (Grzywacz et al., 2009). Each depressive symptom item was measured on a Likert scale to assess the frequency of symptoms in the past week. The four response options included "rarely or none of the time" $(<1$ day, value $=0)$, "some or a little" $(1-2$ days, value $=1)$, "occasionally or a moderate amount of time" (3-4 days, value $=2)$, and 
"most of the time" (5-7 days, value $=3)$. The sum of the ten items and a 10-point cutoff $(\geq 10)$ (Andresen et al., 1994) were used as an indicator of elevated depressive symptoms. Cronbach's alpha was 0.85 .

Work-related factors included work history (length of time worked on horse farms in general), number of hours worked per day, number of days worked per week, and number of hours worked per week. Farm size, measured by the total number of employees (USDOL, 2005), was dichotomized ( $\leq 10$ employees and $>10$ employees) to be more consistent with OSHA Standard 1904 that exempts places of employment with ten or fewer employees from the reporting of occupational injuries and illnesses and the enforcement of occupational standards.

Farmwork practices concerning the barn environment were collected. Measures such as hay storage (in the barn or a separate building), horse bedding material, and hours per week spent in the barn came from previous questionnaires assessing respiratory disease and exposures among equine personnel (Mazan et al., 2009; Rylander et al., 1990). Bedding type assessed both plant (straw) and wood (shavings and sawdust) materials. Questions assessing the occurrence and frequency (hours per week) of job tasks were adapted from the JUSTA study survey (Quandt et al., 2006, 2013) to the horse worker population for the following horse-related tasks: horse handling, raising horses, riding horses, working night watch, and breeding horses. A cumulative measure of hours per week working with horses was created by summing the hours per week of all horse-related tasks. Occurrences of non-horse-related tasks (landscaping and maintenance) were collected as binary variables (yes/no). Work-related stress, a categorical variable (never, sometimes, and often/almost always), measured the frequency of finding work stressful during a typical day and originated from the NIOSH Quality of Worklife module (NIOSH, 2010).

Personal health insurance coverage was measured using a NAWS measure (yes/no) (USDOL, 2010). Other health coverage information was collected using NAWS measures: if the worker becomes sick or injured as a result of work: (1) the farm provides health insurance, (2) the farm pays for the worker's healthcare, and (3) the farm provides workers' compensation (i.e., payment for recuperation) (USDOL, 2005). For workers who reported receiving paid vacation, the number of paid vacation days was collected. The paid sick day measure allowed individuals to report the number of paid sick days received per year or the option of "as many [paid sick days] as I need." Respondents who chose the "as many as I need option" were assigned the average of all respondents.

\section{Analyses}

Descriptive statistics included means, standard deviations, ranges, medians, and interquartile ranges for continuous variables, and frequencies and percentages for categorical variables. Bivariate associations were examined between variables of interest and the dependent variable using chi-square statistics, t-tests, prevalence ratios, and $95 \%$ confidence intervals. The bivariate associations guided interpretations and the input of potential predictors for missed work due to the work-related illness analyses.

Statistical modeling using a generalized linear model (GLM) provided prevalence ratio estimates and the $95 \%$ confidence intervals. Prevalence ratios, rather than odds ratios, were used because the outcome variable (missed work due to work-related illness) was greater than $10 \%$ and to reduce the likelihood of misinterpretation of the odds ratio, which would overestimate the risk ratios for common outcomes (Richardson et al., 2015; Barros and Hirakata, 2003). Only predictors with p-values of 0.20 or less from the bivari- 
ate associations were included in the multivariable analyses (Hosmer and Lemeshow, 2000; Maldonado and Greenland, 1993). For the variable inclusion criteria, it was decided not to limit variables to the 0.05 or less parameter to allow the identification of relevant factors influencing the outcome.

Covariates used in each model included gender (male vs. female), having a child (yes vs. no), living on the farm of employment (yes vs. no), farm size (small vs. not small), work history, sawdust bedding used in barns (yes vs. no), straw bedding used in barns (yes vs. no), current cigarette smoker (yes vs. no), self-assessed general health status ( $\leq$ good vs. $>$ good), stress, and hours worked with horses. Work history was dichotomized into $\leq 9$ years and $>9$ years (referent group) based on the median distribution of this variable. A categorical variable with three levels, "never" (referent group), "sometimes," and "often/almost always," measured the frequency of finding work stressful during a typical workday. The hours spent working with horses per week was dichotomized by the median distribution point as $\leq 16$ hours a week and $>16$ hours a week (referent group).

The first log binomial regression model provided an overall depiction of the relationships between potential predictors and the outcome. Relevant variables (e.g., housing location, work history, and current smoking) were added to the model despite the significance levels being greater than the 0.20 parameter. Variables were removed using interactive backward elimination, in which variables were removed in order of least significance until those remaining with a p-value of 0.05 were left. The second model was gender-specific and examined all the predictors previously examined in the first model. The third model was limited to males only, and interactive backward elimination was used until all remaining variables had a p-value of 0.20 or less. The males-only model was used because female workers represented only $15 \%$ of the sample.

Descriptive univariate statistics examined other personal and work characteristics of the subsample of workers who missed work due to work-related illness. Among this subsample, bivariate associations were calculated for workers who reported any of the top five reported health symptoms and the bedding material used in the barns (sawdust and straw bedding, straw bedding only, and sawdust bedding only) to further understand the association between bedding materials and health symptoms. Data management and analyses were performed using SAS (ver. 9.4, SAS Institute, Inc., Cary, N.C.), with a pvalue of 0.05 denoting statistical significance.

\section{Results}

The 225 participating workers were predominately male (86\%), Mexican (84\%), spoke Spanish (95\%), averaged 35 years of age, and had lived in the U.S. for 14 years (table 1). The majority were married and/or living as married (68\%) and had at least one child age 18 or younger $(65 \%)$. Medical diagnoses of eye irritation, skin irritation, and asthma were $15 \%, 9 \%$, and $4 \%$, respectively. The most prevalent health symptoms were headache $(50 \%)$, throat irritation $(45 \%)$, nasal irritation (41\%), dry cough $(33 \%)$, productive cough $(26 \%)$, and sinus trouble (24\%). Chest tightness $(9 \%)$ and wheezing $(65 \%)$ also occurred. 
Table 1. Horse worker demographic characteristics $(N=225)$.

\begin{tabular}{|c|c|c|}
\hline \multicolumn{3}{|l|}{ Gender } \\
\hline Male $(n, \%)$ & 193 & 85.78 \\
\hline Female $(n, \%)$ & 32 & 14.22 \\
\hline \multicolumn{3}{|l|}{ Age (years) } \\
\hline Mean (SD), range & $35.37(9.62)$ & 18 to 65 \\
\hline Median, IQR & 34.0 & 14.0 \\
\hline \multicolumn{3}{|l|}{ Marital status } \\
\hline Married/living as married $(n, \%)$ & 152 & 67.56 \\
\hline Single $(n, \%)$ & 73 & 32.44 \\
\hline \multicolumn{3}{|l|}{ Has children $\leq 18$ years old } \\
\hline At least one child $(n, \%)$ & 146 & 65.18 \\
\hline No children $(n, \%)$ & 78 & 34.82 \\
\hline \multicolumn{3}{|l|}{ Education } \\
\hline No school $(n, \%)$ & 6 & 2.67 \\
\hline Elementary (primaria, grades $1-6)(n, \%)$ & 85 & 37.78 \\
\hline Middle school (secundaria, grades $7-9)(n, \%)$ & 79 & 35.11 \\
\hline High school (preparatoria, grades $10-12$ and/or GED) $(n, \%)$ & 45 & 20.00 \\
\hline Some college or more $(n, \%)$ & 10 & 4.44 \\
\hline \multicolumn{3}{|l|}{ Time in the U.S. (years) } \\
\hline Mean $(\mathrm{SD})$, range & $14.46(8.44)$ & 0.42 to 45 \\
\hline Median, IQR & 12.00 & 9.50 \\
\hline Lives on farm where works $(n, \%)$ & 59 & 26.22 \\
\hline \multicolumn{3}{|l|}{ Smoking behavior } \\
\hline Ever smoked cigarettes $(N=224)(n, \%)$ & 96 & 42.86 \\
\hline Currently smokes cigarettes $(N=225)(n, \%)$ & 37 & 16.44 \\
\hline \multicolumn{3}{|l|}{ Drinks alcohol in past year $(N=224)$} \\
\hline No drinks $(n, \%)$ & 105 & 46.88 \\
\hline $1-2$ drinks per week $(n, \%)$ & 41 & 18.30 \\
\hline 3-4 drinks per week $(n, \%)$ & 17 & 7.56 \\
\hline $5+$ drinks per week $(n, \%)$ & 34 & 15.18 \\
\hline \multicolumn{3}{|l|}{ General health status } \\
\hline Good health or better $(n, \%)$ & 161 & 71.88 \\
\hline Less than good health $(n, \%)$ & 63 & 28.13 \\
\hline \multicolumn{3}{|l|}{ Depressive symptoms score $(N=219)$} \\
\hline Mean (SD), range & $5.42(5.24)$ & 0 to 28 \\
\hline Median, IQR & 4.00 & 7.00 \\
\hline Missed work due to work-related illness in the past year $(N=218)(n, \%)$ & 69 & 31.65 \\
\hline Attended work when ill in the past year $(N=221)(n, \%)$ & 97 & 43.89 \\
\hline \multicolumn{3}{|l|}{ Reasons for coming into work when ill in the past year $(N=98)^{[a]}$} \\
\hline Need the money $(n, \%)$ & 35 & 35.71 \\
\hline Had to/had no other options $(n, \%)$ & 23 & 23.47 \\
\hline It's my responsibility $(n, \%)$ & 21 & 21.43 \\
\hline Fear of job loss $(n, \%)$ & 9 & 9.18 \\
\hline Don't like missing work $(n, \%)$ & 8 & 8.16 \\
\hline Illness was not too serious $(n, \%)$ & 8 & 8.16 \\
\hline Chronic illness that I just have to work through $(n, \%)$ & 2 & 2.04 \\
\hline
\end{tabular}

Employment characteristics (table 2) reveal that the workers had an average of 10.5 years of general horse farm experience, and worked an average of 48 hours per week (of these hours, an average of 15 were spent working with horses, and 24 hours were spent working in the barn). Predominate job tasks included handling yearlings (70\%), handling mares $(63 \%)$, raising horses $(58 \%)$, landscaping $(57 \%)$, maintenance $(53 \%)$, handling stallions $(22 \%)$, breeding horses $(12 \%)$, working night watch $(7 \%)$, and riding horses $(5 \%)$. Seventy-two percent of the workers received workers' compensation if they 
Table 2. Horse worker work characteristics $(N=\mathbf{2 2 5})$.

\begin{tabular}{lcc}
\hline $\begin{array}{l}\text { General horse farm experience (years) } \\
\text { Mean (SD), range }\end{array}$ & $10.5(7.31)$ & 0.75 to 39 \\
\hline Total hours worked per week & $48.31(5.91)$ & 24 to 72 \\
$\quad$ Mean (SD), range & $15.45(10.51)$ & 0 to 57 \\
\hline $\begin{array}{l}\text { Number of hours per week working with horses } \\
\text { Mean (SD), range }\end{array}$ & $24.38(12.78)$ & 0 to 56 \\
\hline Number of hours per week spent in the barn & 35.33 \\
$\quad$ Mean (SD), range & 75 & 65.33 \\
\hline Has any personal health insurance coverage & 147 \\
$\quad$ Yes $(n, \%)$ & 3 & 71.5 \\
$\quad$ No $(n, \%)$ & 138 & 28.50 \\
$\quad$ Don't know $(n, \%)$ & 55 & 1 to 12 \\
\hline Has worker' compensation for work-related illness or injury $(N=193)$ & 86.88 \\
$\quad$ Yes $(n, \%)$ & $5.25(1.16)$ \\
$\quad$ No $(n, \%)$ & 192 \\
\hline Number of paid sick days per year $(N=100)$ & $8.47(5.01)$ \\
$\quad$ Mean (SD), range & 7.0 \\
\hline Receives paid vacation $(N=221)(n, \%)$ & 0 to 30 \\
\hline Number of paid vacation days per year $(N=193)$ & 3 \\
$\quad$ Mean (SD), range & & \\
Median, IQR & & \\
\hline
\end{tabular}

became injured or ill on the job, and $87 \%$ reported receiving vacation time.

\section{Prevalence of Missed Work}

The prevalence of missing any work due to work-related illness in the past year was $32 \%$. The most commonly cited reasons for coming to work when ill were finances (36\%), having no other options (23\%), and feeling a responsibility to work (21\%).

\section{Work-Related and Demographic Factors Associated with Missed Work}

Statistically significant differences were found by gender, sawdust bedding, straw bedding, general health status, and stress between workers who missed work and those who did not (table 3$)$. Workers who were male $(\mathrm{PR}=0.62,95 \% \mathrm{CI}=0.40,0.95)$, worked where sawdust bedding was used in barns $(\mathrm{PR}=0.51,95 \% \mathrm{CI}=0.29,0.90)$, had good health or greater $(\mathrm{PR}=0.62,95 \% \mathrm{CI}=0.42,0.92)$, and experienced no stress during a typical workday had decreased risk of missing work than the referent group. Workers who used straw bedding in barns had a 3.4 times increased risk of missing work due to work-related illness. Sometimes or often having stress also increased the risk for missed work by at least 2.5 times the risk for those with no stress.

Table 4 shows the prevalence ratios, 95\% confidence intervals, and p-values for the three log binomial regression models. Model 1 is the general model examining all etiological factors for missed work. The significant predictors for model 1 were general health status and stress. Model 2 is the gender-specific model, stratified by males only; the statistically significant predictors were having children, stress, and number of hours spent working with horses. Model 3 is the males-only model that uses $p=0.20$ for factor inclusion. When adjusting model 2 by gender, the significant predictors remained for model 3: having children, stress, and hours spent working with horses. The use of sawdust bedding approached statistical significance $(\mathrm{p}=0.05)$ in model 3 . 
Table 3. Bivariate associations for individual and organizational predictors of missed work due to workrelated illness among Hispanic horse workers in the past year $(N=\mathbf{2 1 8})$.

\begin{tabular}{|c|c|c|c|c|c|c|c|}
\hline & \multicolumn{2}{|c|}{$\begin{array}{c}\text { Missed } \\
\text { Work }\end{array}$} & \multicolumn{2}{|c|}{$\begin{array}{c}\text { No Missed } \\
\text { Work }\end{array}$} & \multirow[b]{2}{*}{ p-Value } & \multirow[b]{2}{*}{$\mathrm{PR}^{[\mathrm{a}]}$} & \multirow[b]{2}{*}{$95 \% \mathrm{CI}^{[\mathrm{a}]}$} \\
\hline & $N$ & $\%$ & $N$ & $\%$ & & & \\
\hline \multicolumn{8}{|l|}{ Demographic characteristics } \\
\hline Gender & & & & & 0.045 & 0.62 & $0.40,0.95$ \\
\hline Male & 54 & 29.03 & 132 & 70.97 & & & \\
\hline Female (ref) & 15 & 46.88 & 17 & 53.13 & & & \\
\hline Has children $\leq 18$ years old & & & & & 0.090 & 1.47 & $0.93,2.33$ \\
\hline At least one child & 50 & 35.21 & 92 & 64.79 & & & \\
\hline No children (ref) & 18 & 24.00 & 57 & 76.00 & & & \\
\hline Lives on farm where works & & & & & 0.437 & 0.83 & $0.52,1.33$ \\
\hline Yes & 16 & 27.59 & 42 & 72.41 & & & \\
\hline No (ref) & 53 & 33.13 & 107 & 66.88 & & & \\
\hline \multicolumn{8}{|l|}{ Farm characteristics } \\
\hline Farm size (number of employees) $)^{[b]}$ & & & & & 0.121 & 1.36 & $0.92,2.01$ \\
\hline Small $(\leq 10)$ & 36 & 37.11 & 61 & 62.89 & & & \\
\hline Not small $(>10)$ (ref) & 33 & 27.27 & 88 & 72.73 & & & \\
\hline General horse farm experience & & & & & 0.263 & 1.25 & $0.84,1.85$ \\
\hline$\leq 9$ years & 38 & 35.19 & 70 & 64.81 & & & \\
\hline$>9$ years $($ ref $)$ & 31 & 28.18 & 79 & 71.82 & & & \\
\hline Sawdust bedding in barn & & & & & 0.012 & 0.51 & $0.29,0.90$ \\
\hline Yes & 11 & 18.64 & 48 & 81.36 & & & \\
\hline No (ref) & 58 & 36.48 & 101 & 63.52 & & & \\
\hline Straw bedding in barn & & & & & 0.029 & 3.38 & $0.90,12.78$ \\
\hline Yes & 67 & 33.84 & 131 & 66.16 & & & \\
\hline No (ref) & 2 & 10.00 & 18 & 90.00 & & & \\
\hline \multicolumn{8}{|l|}{ General health characteristics } \\
\hline Currently smokes cigarettes & & & & & 0.369 & 1.26 & $0.78,2.03$ \\
\hline Yes & 13 & 38.24 & 21 & 61.76 & & & \\
\hline No (ref) & 56 & 30.43 & 128 & 69.57 & & & \\
\hline General perceived health status & & & & & 0.019 & 0.62 & $0.42,0.92$ \\
\hline Good health or better & 42 & 27.10 & 113 & 72.90 & & & \\
\hline Less than good health (ref) & 27 & 43.55 & 35 & 56.45 & & & \\
\hline \multicolumn{8}{|l|}{ Mental health characteristics } \\
\hline Depressive symptoms score & & & & & 0.184 & 0.71 & $0.45,1.14$ \\
\hline Non-elevated symptoms $(\leq 10)$ & 56 & 29.95 & 131 & 70.05 & & & \\
\hline Elevated symptoms $(>10)$ (ref) & 13 & 41.94 & 18 & 58.06 & & & \\
\hline Finds work stressful on a typical day & & & & & $0.002^{[\mathrm{c}]}$ & & \\
\hline Sometimes & 37 & 35.92 & 66 & 64.08 & 0.003 & 2.48 & $1.28,4.77$ \\
\hline Often/almost always & 23 & 43.40 & 30 & 20.13 & 0.001 & 2.99 & $1.52,5.89$ \\
\hline Never (ref) & 9 & 14.52 & 53 & 85.48 & & & \\
\hline \multicolumn{8}{|l|}{ Task characteristic } \\
\hline Hours spent working with horses & & & & & 0.055 & 1.50 & $0.98,2.31$ \\
\hline$\leq 16$ hours per week & 47 & 36.17 & 81 & 63.28 & & & \\
\hline$>16$ hours per week (ref) & 22 & 24.44 & 68 & 75.56 & & & \\
\hline
\end{tabular}

[a] $\mathrm{PR}=$ prevalence ratio; $95 \% \mathrm{CI}=95 \%$ confidence interval

[b] Farm size is consistent with OSHA regulations on reportable work illnesses/injuries.

[c] Indicates the p-value for all three levels of this variable. 
Table 4. General and gender-specific log binomial regression models for predictors of missed work due to work-related illness among Hispanic horse workers in the past year. Values are prevalence ratio, $95 \%$ confidence interval, and p-value (in parentheses).

\begin{tabular}{|c|c|c|c|}
\hline & $\begin{array}{l}\text { Model 1: } \\
\text { General } \\
\text { Etiological } \\
(N=216)\end{array}$ & $\begin{array}{c}\text { Model 2: } \\
\text { Stratified by } \\
\text { Male Gender } \\
(N=185)\end{array}$ & $\begin{array}{c}\text { Model 3: } \\
\text { Stratified by } \\
\text { Male Gender } \\
(\mathrm{p}<0.20) \\
(N=185)\end{array}$ \\
\hline \multicolumn{4}{|l|}{ Demographic characteristics } \\
\hline Male vs. female & $\begin{array}{c}0.98 \\
0.60,1.59 \\
(0.93)\end{array}$ & - & - \\
\hline Has children $\leq 18$ or younger vs. none & $\begin{array}{c}1.57 \\
1.0,2.47 \\
(0.05) \\
\end{array}$ & $\begin{array}{c}1.86 \\
1.09,3.16 \\
(0.02) \\
\end{array}$ & $\begin{array}{c}1.71 \\
1.03,2.84 \\
(0.04) \\
\end{array}$ \\
\hline Lives on farm where works vs. does not & $\begin{array}{c}0.99 \\
0.62,1.60 \\
(0.98)\end{array}$ & $\begin{array}{c}1.07 \\
0.61,1.89 \\
(0.82)\end{array}$ & - \\
\hline \multicolumn{4}{|l|}{ Farm characteristics } \\
\hline Small farm vs. not small farm & $\begin{array}{c}1.25 \\
0.87,1.82 \\
(0.23)\end{array}$ & $\begin{array}{c}1.03 \\
0.66,1.61 \\
(0.9) \\
\end{array}$ & - \\
\hline $\begin{array}{l}\leq 9 \text { years vs. }>9 \text { years of general horse } \\
\text { farm experience }\end{array}$ & $\begin{array}{c}1.29 \\
0.85,1.95 \\
(0.23)\end{array}$ & $\begin{array}{c}1.31 \\
0.84,2.04 \\
(0.23) \\
\end{array}$ & - \\
\hline Sawdust bedding vs. none & $\begin{array}{c}0.68 \\
0.37,1.26 \\
(0.22) \\
\end{array}$ & $\begin{array}{c}0.6 \\
0.30,1.19 \\
(0.14)\end{array}$ & $\begin{array}{c}0.54 \\
0.29,1.00 \\
(0.05) \\
\end{array}$ \\
\hline Straw bedding vs. none & $\begin{array}{c}1.53 \\
0.36,6.47 \\
(0.57)\end{array}$ & $\begin{array}{c}1.42 \\
0.33,6.17 \\
(0.64)\end{array}$ & - \\
\hline $\begin{array}{l}\leq 16 \text { hours vs. }>16 \text { hours per week } \\
\text { spent working with horses }\end{array}$ & $\begin{array}{c}1.5 \\
0.97,2.34 \\
(0.07) \\
\end{array}$ & $\begin{array}{c}1.98 \\
1.19,3.28 \\
(0.01) \\
\end{array}$ & $\begin{array}{c}1.87 \\
1.15,3.05 \\
(0.01) \\
\end{array}$ \\
\hline \multicolumn{4}{|l|}{ General health characteristics } \\
\hline Currently smokes cigarettes vs. does not & $\begin{array}{c}1.41 \\
0.88,2.27 \\
(0.16) \\
\end{array}$ & $\begin{array}{c}1.31 \\
0.76,2.25 \\
(0.34)\end{array}$ & - \\
\hline$\geq$ Good vs. $<$ good health status & $\begin{array}{c}0.69 \\
0.49,0.98 \\
(0.04)\end{array}$ & $\begin{array}{c}0.71 \\
0.46,1.10 \\
(0.12)\end{array}$ & $\begin{array}{c}0.72 \\
0.48,1.08 \\
(0.11)\end{array}$ \\
\hline \multicolumn{4}{|l|}{ Mental health characteristics } \\
\hline $\begin{array}{l}\text { Non-elevated }(\leq 10) \text { vs. elevated }(>10) \\
\text { depressive symptoms }\end{array}$ & $\begin{array}{c}0.71 \\
0.44,1.14 \\
(0.16)\end{array}$ & $\begin{array}{c}0.69 \\
0.38,1.26 \\
(0.23)\end{array}$ & $\begin{array}{c}0.69 \\
0.40,1.18 \\
(0.18)\end{array}$ \\
\hline $\begin{array}{l}\text { Sometimes finds vs. does not find work } \\
\text { stressful }\end{array}$ & $\begin{array}{c}2.05 \\
1.05,4.01 \\
(0.035)\end{array}$ & $\begin{array}{c}2.52 \\
1.18,5.37 \\
(0.02)\end{array}$ & $\begin{array}{c}2.58 \\
1.25,5.32 \\
(0.01)\end{array}$ \\
\hline $\begin{array}{l}\text { Often/almost always finds vs. does not } \\
\text { find work stressful }\end{array}$ & $\begin{array}{c}2.64 \\
1.30,5.37 \\
(0.01)\end{array}$ & $\begin{array}{c}3.09 \\
1.39,6.86 \\
(0.01)\end{array}$ & $\begin{array}{c}2.93 \\
1.36,6.29 \\
(0.01)\end{array}$ \\
\hline
\end{tabular}

\section{Characteristics of Workers Who Missed Work Due to Work-Related Illness}

Among those who missed work due to work-related illness, the average number of missed workdays was seven $(\mathrm{SD}=19$; median $=2)$, with a range of 1 to 150 days in the past year. The mean number of paid sick days among those who missed work was 5.2 
$(\mathrm{SD}=1.1$, range $=1$ to $7, n=38)$. Of those who missed work, $70 \%$ reported being able to call in sick or take the day off when sick without worrying about job loss (table 5). Additionally, $57 \%$ of workers who missed work also reported going to work when ill in the past year. The most common health symptoms reported in the past year were throat irritation (58\%), headache (57\%), nasal irritation (52\%), dry cough (45\%), and productive cough $(33 \%)$. Of those reporting at least one symptom, $74 \%$ noted that their symptoms improved while away from the barn for more than one day. In addition, $19 \%$ of workers who missed work were current smokers. Moreover, $42 \%$ of those missing work reported having health insurance (55\% reported that their farm provides health insurance, and $75 \%$ reported that their farm pays for healthcare if they acquire a work-related injury or illness), and 79\% reported that their farm provides workers' compensation coverage. Seventy-eight percent received paid vacation days.

To further understand the association between bedding materials and health symptoms, bivariate associations were calculated for workers who reported any of the top five reported symptoms (headache, throat irritation, nasal irritation, dry cough, and productive

Table 5. Characteristics of horse workers who missed work due to work-related injury or illness in the past year $(N=69)$.

Worker characteristics

Had any of the following symptoms in the past year ${ }^{[a]}$

Headache $(n, \%)$

Throat irritation $(n, \%)$

Nasal irritation $(n, \%)$

Dry cough $(n, \%)$

Productive cough $(n, \%)$

Sinus trouble $(n, \%)$

Chest tightness $(n, \%)$

Wheezing $(n, \%)$

Symptoms improved when away from barn for at least one day

$(N=46)(n, \%)$

Had symptoms that caused worker to miss work or normal activities $(N=48)(n, \%)$

Woke up at night because of wheezing, whistling, coughing, or difficulty breathing $(N=49)(n, \%)$

Attended work when ill in the past year $(N=68)(n, \%)$

Work characteristics

Hours worked per week

Mean (SD), Range

Farm provides health insurance for work-related injury or illness $(N=66)(n, \%)$

Farm pays for healthcare for work-related injury or illness $(N=64)(n, \%)$

Farm provides workers' compensation if worker is injured or becomes ill on the job $(N=62)(n, \%)$

Worker can call in sick or take day off when sick without

worrying about job loss $(N=55)$

Yes $(n, \%)$

No $(n, \%)$

Sometimes $(n, \%)$

Receives pay on days when sick

Yes $(n, \%)$

No $(n, \%)$

Sometimes $(n, \%)$

Receives paid vacation days $(n, \%)$

$\begin{array}{lll}28 & 69.57\end{array}$

$7 \quad 10.14$

$14 \quad 20.29$

Individual workers may have reported more than one health condition or symptom. 
cough). Workers who used both sawdust and straw bedding had a two-fold increased risk of reporting at least one health symptom compared to workers who used only sawdust bedding $(\mathrm{PR}=2.05,95 \% \mathrm{CI}=1.03,4.05)$. Workers who used only straw bedding were 1.9 times more likely to report at least one health symptom compared to workers who used only sawdust bedding $(\mathrm{PR}=1.93,95 \% \mathrm{CI}=0.99,3.75)$.

\section{Discussion}

This study examined missed work due to work-related illness among Latino horse workers. Of the workers interviewed, $32 \%$ had suffered a work-related illness in the past year that they believed was severe enough to miss work. Missed work due to workrelated illness may have served as a proxy for the general severity of illness, as it assumes the illness was severe enough to warrant loss of pay or use of sick leave. Furthermore, $44 \%$ of the workers reported going to work despite being ill. The horse workers in this study attended work when ill due to financial pressure, which may or may not include being paid only when they work and the lack of paid sick leave. This finding coincides with other farmworker groups who must work to avoid further economic hardship. Attending work when sick contrasts with the current health recommendation for workers to remain home to prevent spreading disease to their fellow workers. Further, because only $33 \%$ of the horse workers reported having health insurance, which is a critical determinant of access to healthcare (Morales et al., 2002), workers with a work-related illness may not receive appropriate or timely medical treatment.

The workers in this study were interviewed before implementation of the Affordable Care Act (ACA), which may have made healthcare coverage more feasible for agricultural workers. However, ACA-mandated coverage is limited to farms with 50 or more employees. Therefore, workers on smaller farms ( $<50$ employees), which comprise at least $85 \%$ of the horse farms in the study region (Nutt et al., 2011), are still not receiving necessary healthcare and prevention services.

In addition, $72 \%$ of the horse workers reported having workers' compensation coverage for work-related illness or injury in a non-mandated area. This contrasts with other seasonal and temporary farmworkers who do not have this coverage, often due to their employment status, lack of state mandates, and documentation status, causing them to forgo needed care.

This study suggests that wood bedding materials, such as sawdust, may protect against work-related illness, while plant materials, such as straw, may increase a worker's chance of missing work due to a work-related illness. Bedding material is used to keep horses clean and reduce the level of manure gases (Airaksinen, 2006). Farms should assess bedding quality and the potential impact on worker health, e.g., absorption capacity, dustiness, microbial quality, ease of handling, and manure decomposition rate (Westendorf and Krogmann, 2013; Thomas, 2007) when choosing bedding materials, as well as incorporate bedding storage and work practices that help improve the health of workers and horses. Bedding practices could include drying hay and straw before storage to help prevent mold growth (Kirkhorn, 2002) and lightly wetting straw bedding (if dusty) before mucking stalls (Thomas, 2007).

Our findings suggest that employers could consider using sawdust instead of straw bedding. Sawdust is easily cleaned up, compostable, absorbent, has low palatability for horses, and its dust is manageable (Westendorf and Krogmann, 2013). Nevertheless, 
there is potential for sawdust to irritate the noses and eyes of horses (Thomas, 2007), as well as those of workers. Symptomatic persons should be monitored, as $74 \%$ of the health symptoms of workers improved when they were away from the barn for at least one day. These symptoms included headache, throat irritation, nasal irritation, and cough. As the market for straw increases, farms could opt for sawdust bedding, if available. On further examination of bedding materials and health symptoms, a significant association was found in which workers who used both sawdust and straw bedding were twice as likely to report a health symptom as workers who used only sawdust bedding.

Our study finding that $65 \%$ of the horse workers have minor children is comparable to U.S. Census results showing that $62 \%$ of Hispanic households have children under the age of 18 (CDC, 2014). Children are an important part of Hispanic culture (familismo) (CDC, 2008). Workers who were parents had a 57\% increased risk of missing work compared to non-parents, and this risk increased to $71 \%$ when examining only male workers. The increased risk may be due to children serving as additional disease vectors, bringing home illnesses that may be manifested as the health symptoms that are commonly found among farmworkers (Garcia et al., 1996). Furthermore, this study's findings concerning children support previous studies that showed the influence of family characteristics on missed work time (Senel and Senel, 2012).

Self-reported health status was a significant etiological factor for missed work due to work-related illness for all workers, which aligns with other research linking illnessrelated absenteeism to poorer self-reported health (Jenkins, 2014; Eriksson et al., 2008). More workers in this study assessed their health as good or better, which contradicts other research showing that foreign-born workers more often self-rate their health as poor or fair (Grzywacz et al., 2014; Franzini and Fernandez-Esquer, 2004). The higher health rating may indicate that our worker group is more optimistic about their health and potentially healthier than other study populations and may support the Hispanic paradox (Franzini and Fernandez-Esquer, 2004) or healthy immigrant effect (Morales et al., 2002).

The finding of stress as a significant predictor of missed work is similar to other studies (Head et al., 2006; Melchior et al., 2003) and supports previous findings on the effects of stress on health-related outcomes. Sources of work-related stress may include work demands, supervisor/worker relationships, and work communication practices (Winkelman et al., 2013).

The literature notes that horses are a prevalent workplace hazard for horse workers, putting them at risk of injury (Swanberg et al., 2013, 2016; Iba et al., 2001). However, this study found that workers who worked with horses for more than 16 hours per week were less likely to miss work due to work-related illness compared to workers who worked with horses for 16 hours or less per week. This may indicate that workers who spent fewer hours with horses are subjected to other exposures as they perform other jobs (in absence of horse contact) on the farm. These jobs may include maintenance, cleaning barns, mucking stalls, and landscaping, which may expose the workers to poor air quality (e.g., dry climates), pesticides, chemicals, etc. In addition, this finding may be related to job seniority and duration of employment, as senior workers may be given more complex tasks and/or have cumulative exposures to work hazards.

\section{Limitations}

Despite its novel findings, this study has its limitations. Actively working farmworkers participated in the study, which may underestimate the true prevalence of missed 
work due to the selection bias of the healthy worker effect. Recall bias may be an issue as well, as the data were based on self-reporting by the workers. Self-reported data may make it difficult to estimate the true characteristics and associations of the outcome of interest, as the worker self-reported measures were not confirmed through employer or healthcare records, nor were specifics gathered on the illnesses contributing to missing work. However, the worker perspective allows additional awareness of work-related illnesses compared to using only employer reports, which have been criticized for underreporting (Rosenman et al., 2006), especially in agriculture where no specific OSHA regulations apply and on small farms (e.g., $95 \%$ of U.S. farms are small farms; Hansen and Donhoe, 2003) that are often exempt from compliance with general industry regulations (e.g., OSHA Standard 1904).

This study did not use employers to access workers in an effort to protect the workers from potential job loss or other adverse outcomes due to the sharing of potentially sensitive information. However, the use of self-reported information involves limitations and bias, especially the potential influence of Hispanic culture on health and health-seeking behaviors. This study offers insight into what illnesses the workers believe they acquired from the work environment, even though clinical diagnoses and employer reports were not obtained or assessed to confirm the worker self-reports. The worker illnesses may not have required emergency or medical care, which also may contribute to underreporting.

This study may not capture migrant workers, who have their own vulnerabilities with respect to lifestyle, because the inclusion criteria required employment for nine months on a farm. Inferences are limited to Latino horse workers. This study also did not investigate disparities within the Latino/Hispanic ethnicity because the majority (84\%) of the participants were Mexican-born. However, this study relied on collaborations among academia, industry, and the community to help reach a vulnerable and dispersed worker population (Swanberg et al., 2016). This study also employed trained community health workers (promotoras) to capture the occupational health experiences of a hard-to-reach Latino population.

\section{Conclusion}

Given the dearth of research on missed work due to work-related illnesses among Latino horse workers, this study adds value by describing risk factors associated with missed work time due to work-related illness while controlling for a large number of covariates. This study revealed that work conditions, including stress at work, type of horse bedding (e.g., straw), and time spent with horses, can have an influence on missed work due to work-related illness. Missed work is costly for farms. Future research is needed to understand the factors that contribute to worker stress and why the type of horse bedding may lead to missed work, such as the respiratory illnesses that we found to be significantly associated with bedding type. Farm owners are encouraged to assess their bedding type and the health effects on both the workers and horses.

Although the focus of this study was occupational safety and health among Latino horse workers, reporting poor general health and having at least one minor child were significant predictors of missed work. This finding may suggest that male horse workers participate in the care of their children, which is an important finding for horse farms and managers. As such, it would be important for farm owners and managers to create a work environment that encourages workers to discuss family matters with their supervisors. It 
is possible that workers may not share such information with their managers or supervisors, and therefore they take a full day off work when perhaps they only need to take a half day. This finding calls for future research into the work-family circumstances of Latino horse workers and the influence of these factors on job-related outcomes. Future research should also examine work-related illnesses in horse work, including personal and work-related factors, in order to help diminish the occupational health disparities among Hispanic workers, who are more likely to be employed in hazardous work.

\section{Acknowledgements}

The work presented in this article was supported by CDC/NIOSH Cooperative Agreement No. 5U54OH007547-14. The contents of this article are solely the responsibility of the authors and do not necessarily represent the official views of CDC/NIOSH. The publication of this article was paid for by the Southeast Center for Agricultural Health and Injury Prevention. The authors thank the farmworkers who participated in this study, the four promotoras who collected data from them, and the industry and the community advisory council members who guided the project.

\section{References}

AHC. (2005). 2005 National economic impact of the U.S. horse industry. Washington, DC: American Horse Council.

Airaksinen, S. (2006). Bedding and manure management in horse stables: Its effect on stable air quality, paddock hygiene and the compostability and utilization of manure. Natural Environ. Sci., 190, 18-25. Retrieved from http://epublications.uef.fi/pub/urn_isbn_951-27-0443-9/urn_isbn_95127-0443-9.pdf

Alderete, E., Vega, W. A., Kolody, B., \& Aguilar-Gaxiola, S. (1999). Depressive symptomatology: Prevalence and psychosocial risk factors among Mexican migrant farmworkers in California. $J$. Commun. Psych., 27(4), 457-471. https://doi.org/10.1002/(SICI)15206629(199907)27:4<457::AID-JCOP7>3.0.CO;2-D

Alderete, E., Vega, W. A., Kolody, B., \& Aguilar-Gaxiola, S. (2000). Lifetime prevalence of and risk factors for psychiatric disorders among Mexican migrant farmworkers in California. American J. Public Health, 90(4), 608-614. https://doi.org/10.2105/AJPH.90.4.608

Andresen, E. M., Malmgren, J. A., Carter, W. B., \& Patrick, D. L. (1994). Screening for depression in well older adults: Evaluation of a short form of the CES-D. American J. Prev. Med., 10(2), 77-84.

Arcury, T. A. (2009). Farmworkers and visual impairment instrument. Winston-Salem, NC: Wake Forest University School of Medicine.

Arcury, T. A., \& Marín, A. J. (2009). Latino/Hispanic farmworkers and farm work in the eastern United States: The context for health, safety, and justice. In S. A. Quandt \& T. A. Arcury (Eds.), Latino farmworkers in the eastern United States: Health, safety, and justice (pp. 15-36). New York, NY: Springer. https://doi.org/10.1007/978-0-387-88347-2_2

Barros, A. J., \& Hirakata, V. N. (2003). Alternatives for logistic regression in cross-sectional studies: An empirical comparison of models that directly estimate the prevalence ratio. BMC Med. Res. Method., 3(1), 21. https://doi.org/10.1186/1471-2288-3-21

BLS. (2015a). Employer-reported workplace injuries and illnesses - 2014. Washington, DC: Bureau of Labor Statistics. Retrieved from http://www.bls.gov/news.release/pdf/osh.pdf

BLS. (2015b). Nonfatal occupational injuries and illnesses requiring days away from work, 2014. Washington, DC: Bureau of Labor Statistics. Retrieved from http://www.bls.gov/news.release/pdf/osh2.pdf

BLS. (2016). Industries at a glance: Animal production: NAICS 112. Washington, DC: Bureau of Labor Statistics.

Castañeda, H., Kline, N., \& Dickey, N. (2010). Health concerns of migrant backstretch workers at 
horse racetracks. J. Health Care Poor Underserv., 21(2), 489-503.

https://doi.org/10.1353/hpu. 0.0300

CDC. (2008). Work-related injury deaths among Hispanics: United States, 1992-2006. MMWR, 57, 597-600. Atlanta, GA: Centers for Disease Control and Prevention.

CDC. (2014). Cultural insights: Communicating with Hispanics/Latinos. CDC Healthy Communities Program. Atlanta, GA: Centers for Disease Control and Prevention. Retrieved from

http://www.cdc.gov/nccdphp/dch/programs/healthycommunitiesprogram/tools/pdf/hispanic_latino $\mathrm{s}$ insight.pdf

Crain, R., Grzywacz, J. G., Schwantes, M., Isom, S., Quandt, S. A., \& Arcury, T. A. (2012). Correlates of mental health among Latino farmworkers in North Carolina. J. Rural Health, 28(3), 277-285. https://doi.org/10.1111/j.1748-0361.2011.00401.x

Culp, K., \& Umbarger, M. (2004). Seasonal and migrant agricultural workers: A neglected work force. $A A O H N J$., 52(9), 383-390.

DDAF. (2014). 2014 Kentucky thoroughbred horse farm compensation and benefits survey. Lexington, KY: Dean Dorton Allen Ford. Retrieved from http://deandorton.com/wpcontent/uploads/2016/01/2014-Kentucky-Thoroughbred-Horse-Farm-Compensation-and-BenefitsSurvey-web.pdf

Eriksson, H.-G., von Celsing, A.-S., Wahlstrom, R., Janson, L., Zander, V., \& Wallman, T. (2008). Sickness, absence, and self-reported health: A population-based study of 43,600 individuals in central Sweden. BMC Public Health, 8(1), 1-7. https://doi.org/10.1186/1471-2458-8-426

Franzini, L., \& Fernandez-Esquer, M. E. (2004). Socioeconomic, cultural, and personal influences on health outcomes in low-income Mexican-origin individuals in Texas. Soc. Sci. Med., 59(8), 16291646. https://doi.org/10.1016/j.socscimed.2004.02.014

Garcia, J., Matheny Dresser, K., \& Zerr, A. (1996). Respiratory health of Hispanic migrant farm workers in Indiana. American J. Ind. Med., 29(1), 23-32.

Goldberg, R. J., \& Steury, S. (2001). Depression in the workplace: Costs and barriers to treatment. Psychiatr. Serv., 52(12), 1639-1643. https://doi.org/10.1176/appi.ps.52.12.1639

Grzywacz, J. G., Alterman, T., Gabbard, S., Shen, R., Nakamoto, J., Carroll, D. J., \& Muntaner, C. (2014). Job control, psychological demand, and farmworker health: Evidence from the National Agricultural Workers Survey. J. Occup. Environ. Med., 56(1), 66-71. https://doi.org/10.1097/JOM.0000000000000025

Grzywacz, J. G., Alterman, T., Muntaner, C., Shen, R., Li, J., Gabbard, S., ... Carroll, D. J. (2009). Mental health research with Latino farmworkers: A systematic evaluation of the short CES-D. $J$. Immigr. Minor. Health, 12(5), 652-658. https://doi.org/10.1007/s10903-009-9311-2

Grzywacz, J. G., Quandt, S. A., Chen, H., Isom, S., Kiang, L., Vallejos, Q., \& Arcury, T. A. (2010). Depressive symptoms among Latino farmworkers across the agricultural season: Structural and situational influences. Cultur. Divers. Ethnic Minor. Psych., 16(3), 335-343. https://doi.org/10.1037/a0019722

Hansen, E., \& Donohoe, M. (2003). Health issues of migrant and seasonal farmworkers. J. Health Care Poor Underserv., 14(2), 153-164. https://doi.org/10.1353/hpu.2010.0790

Head, J., Kivimaki, M., Martikainen, P., Vahtera, J., Ferrie, J. E., \& Marmot, M. G. (2006). Influence of change in psychosocial work characteristics on sickness absence: The Whitehall II study. $J$. Epidemiol. Commun. Health, 60(1), 55-61. https://doi.org/10.1136/jech.2005.038752

Hiott, A. E., Grzywacz, J. G., Davis, S. W., Quandt, S. A., \& Arcury, T. A. (2008). Migrant farmworker stress: Mental health implications. J. Rural Health, 24(1), 32-39. https://doi.org/10.1111/j.1748-0361.2008.00134.x

Hosmer, D., \& Lemeshow, S. (2000). Applied logistic regression. New York, NY: Wiley. https://doi.org/10.1002/0471722146

Hovey, J. D., \& Magana, C. G. (2002). Exploring the mental health of Mexican migrant farm workers in the Midwest: Psychosocial predictors of psychological distress and suggestions for prevention and treatment. J. Psych., 136(5), 493-513. https://doi.org/10.1080/00223980209605546

Iba, K., Wada, T., Kawaguchi, S., Fujisaki, T., Yamashita, T., \& Ishii, S. (2001). Horse-related 
injuries in a thoroughbred stabling area in Japan. Arch. Orthop. Trauma Surg., 121(9), 501-504. https://doi.org/10.1007/s004020100278

Jenkins, K. R. (2014). How valid are self-reports of illness-related absence? Evidence from a university employee health management program. Pop. Health Mgmt., 17(4), 211-217. https://doi.org/10.1089/pop.2013.0087

Kim-Godwin, Y. S., Maume, M. O., \& Fox, J. A. (2014). Depression, stress, and intimate partner violence among Latino migrant and seasonal farmworkers in rural southeastern North Carolina. $J$. Immigr. Minor. Health, 16(6), 1217-1224. https://doi.org/10.1007/s10903-014-0007-x

Kirkhorn, S. (2002). Agricultural respiratory hazards and disease. Partners in Agricultural Health, Module IV. Retrieved from http://worh.org/files/AgHealth/resp.pdf

Kirkhorn, S. R., \& Schenker, M. B. (2002). Current health effects of agricultural work: Respiratory disease, cancer, reproductive effects, musculoskeletal injuries, and pesticide-related illnesses. $J$. Agric. Saf. Health, 8(2), 199-214. https://doi.org/10.13031/2013.8432

Kohout, F. J., Berkman, L. F., Evans, D. A., \& Cornoni-Huntley, J. (1993). Two shorter forms of the CES-D depression symptoms index. J. Aging Health, 5(2), 179-193. https://doi.org/10.1177/089826439300500202

Krause, N., Frank, J., Dasinger, L., Sullivan, T., \& Sinclair, S. (2001). Determinants of duration of disability and return-to-work after work-related injury and illness: Challenges for future research. American J. Ind. Med., 40(4), 464-484.

Langley, R., \& Morris, T. (2009). That horse bit me: Zoonotic infections of equines to consider after exposure through the bite or the oral/nasal secretions. J. Agromed., 14(3), 370-381. https://doi.org/10.1080/10599240903058087

Loving, N. S. (2009). Cautions when administering medications. The Horse (1 Nov. 2009). Lexington, KY: The Horse. Retrieved from https://thehorse.com/153672/cautions-when-administeringmedications/

Lushniak, B. D. (2003). The importance of occupational skin diseases in the United States. Intl. Arch. Occup. Environ. Health, 76(5), 325-330. https://doi.org/10.1007/s00420-002-0417-2

Maldonado, G., \& Greenland, S. (1993). Simulation study of confounder-selection strategies. American J. Epidemiol., 138(11), 923-936. https://doi.org/10.1093/oxfordjournals.aje.a116813

May, J. J. (2009). Occupational injury and illness in farmworkers in the eastern United States. In S. A. Quandt \& T. A. Arcury (Eds.), Latino farmworkers in the eastern United States: Health, safety, and justice (pp. 71-101). New York, NY: Springer. https://doi.org/10.1007/978-0-387-88347-2_4

Mazan, M. R., Svatek, J., Maranda, L., Christiani, D., Ghio, A., Nadeau, J., \& Hoffman, A. M. (2009). Questionnaire assessment of airway disease symptoms in equine barn personnel. Occup. Med., 59(4), 220-225. https://doi.org/10.1093/occmed/kqp003

Mazzoni, S. E., Boiko, P. E., Katon, W. J., \& Russo, J. (2007). Depression and disability in seasonal and migrant Hispanic agricultural workers. Gen. Hosp. Psychiatry, 29(5), 450-453. https://doi.org/10.1016/j.genhosppsych.2007.06.00

McDonald, J. C., Beck, M. H., Chen, Y., \& Cherry, N. M. (2006). Incidence by occupation and industry of work-related skin diseases in the United Kingdom, 1996-2001. Occup. Med., 56(6), 398-405. https://doi.org/10.1093/occmed/kq1039

Melchior, M., Niedhammer, I., Berkman, L. F., \& Goldberg, M. (2003). Do psychosocial work factors and social relations exert independent effects on sickness absence? A six-year prospective study of the GAZEL cohort. J. Epidemiol. Comm. Health, 57(4), 285-293.

https://doi.org/10.1136/jech.57.4.285

Morales, L. S., Lara, M., Kington, R. S., Valdez, R. O., \& Escarce, J. J. (2002). Socioeconomic, cultural, and behavioral factors affecting Hispanic health outcomes. J. Health Care Poor Underserv. 13(4), 477-503. https://doi.org/10.1177/104920802237532

Myers, J., \& Cole, H. (2008). On-site fish farm structured interview form 050908. Aquaculture Safety and Health. Lexington, KY: Southeast Center for Agricultural Health and Injury Prevention.

NIOSH. (2010). General Social Survey 2010 Section D: Quality of Worklife Module (QWL). Washington, DC: National Institute for Occupational Safety and Health. Retrieved from 
http://www.cdc.gov/niosh/topics/stress/pdfs/QWL2010.pdf

NIOSH. (2012). Occupational health disparities: Inputs: Occupational safety and health risks. Washington, DC: National Institute for Occupational Safety and Health. Retrieved from http://www.cdc.gov/niosh/programs/ohd/risks.html

Nutt, P., Clark, M., Graycarek, R., Hall, C. T., \& Roenker, J. (2011). The Kentucky thoroughbred breeding industry and state programs that assist the equine industry. Frankfort, KY: Legislative Research Commission. Retrieved from http:/www.lrc.ky.gov/lrcpubs/RR406.pdf

Orrenius, P. M., \& Zavodny, M. (2009). Do immigrants work in riskier jobs? Demography, 46(3), 535-551. https://doi.org/10.1353/dem.0.0064

Quandt, S., Coates, M., \& Burke, B. (2013). Justice and health for Latino poultry workers (JUSTA) study survey (ver. 5.1). Winston-Salem, NC: Wake Forest University School of Medicine and Centro Latino of Caldwell County.

Quandt, S., Grzywacz, J. G., Maran, A., Carrillo, L., Coates, M., Burke, B., \& Arcury, T. A. (2006). Illnesses and injuries reported by Latino poultry workers in western North Carolina. American J. Ind. Med., 49(5), 343-351. https://doi.org/10.1002/ajim.20299

Rautiainen, R. H., Ohsfeldt, R., Sprince, N. L., Donham, K. J., Burmeister, L. F., Reynolds, S. J., ... Zwerling, C. (2005). Cost of compensated injuries and occupational diseases in agriculture in Finland. J. Agromed., 10(3), 21-29. https://doi.org/10.1300/J096v10n03 03

Reed, D. B. (2004). The risky business of production agriculture: Health and safety for farm workers. AAOHN J., 52(9), 401-409.

Richardson, D. B., Kinlaw, A. C., MacLehose, R. F., \& Cole, S. R. (2015). Standardized binomial models for risk or prevalence ratios and differences. Intl. J. Epidemiol., 44(5), 1660-1672. https://doi.org/10.1093/ije/dyv137

Rosenman, K. D., Kalush, A., Reilly, M. J., Gardiner, J. C., Reeves, M., \& Luo, Z. (2006). How much work-related injury and illness is missed by the current national surveillance system? J. Occup. Environ. Med., 48(4), 357-365. https://doi.org/10.1097/01.jom.0000205864.81970.63

Rylander, R., Peterson, Y., \& Donham, K. J. (1990). Questionnaire evaluating organic dust exposure. American J. Ind. Med., 17(1), 121-126. https://doi.org/10.1002/ajim.4700170142

Schefstad, A. J., Tiegel, S. A., \& Jones, A. C. (1999). Treating a visible problem within a hidden population. Employ. Assist. Qtly., 14(4), 17-32. https://doi.org/10.1300/J022v14n04_02

Senel, B., \& Senel, M. (2012). The cost of absenteeism and the effect of demographic characteristics and tenure on absenteeism. Interdisc. J. Contemp. Res. Bus., 4(5), 1142-1151.

Speed, H., \& Andersen, M. B. (2008). The health and welfare of thoroughbred horse trainers and stable employees. Melbourne, Australia: Victoria University, Centre for Ageing, Rehabilitation, Exercise, and Sport.

Spurzem, J. R., Romberger, D. J., \& Von Essen, S. G. (2002). Agricultural lung disease. Clin. Chest Med., 23(4), 795-810. https://doi.org/10.1016/S0272-5231(02)00024-2

Steege, A., Baron, S., \& Chen, X. (2009). Occupational health of hired farmworkers in the United States: National Agricultural Workers Survey, Occupational Health Supplement, 1999. Washington, DC: National Institute for Occupational Safety and Health. Retrieved from https:/www.cdc.gov/niosh/docs/2009-119/pdfs/2009-119.pdf

Stocks, S. J., Turner, S., Carder, M., Hussey, L., McNamee, R., \& Agius, R. M. (2010). Medically reported work-related ill-health in the UK agricultural sector. Occup. Med., 60(5), 340-347. https://doi.org/10.1093/occmed/kqq038

Stoecklin-Marois, M. T., Hennessy-Burt, T. E., \& Schenker, M. B. (2011). Engaging a hard-to-reach population in research: Sampling and recruitment of hired farm workers in the MICASA study. $J$. Agric. Saf. Health, 17(4), 291-302. https://doi.org/10.13031/2013.39803

Strong, L. L., \& Zimmerman, F. J. (2005). Occupational injury and absence from work among African American, Hispanic, and non-Hispanic white workers in the national longitudinal survey of youth. American J. Public Health, 95(7), 1226-1232. https://doi.org/10.2105/AJPH.2004.044396

Swanberg, J. E., Clouser, J. M., \& Westneat, S. (2012). Work organization and occupational health: Perspectives from Latinos employed on crop and horse breeding farms. American J. Ind. Med., 
55(8), 714-728. https://doi.org/10.1002/ajim.22032

Swanberg, J. E., Clouser, J. M., Bush, A., \& Westneat, S. (2016). From the horse worker's mouth: A detailed account of injuries experienced by Latino horse workers. J. Immigr. Minor. Health, 18(3), 513-521. https://doi.org/10.1007/s10903-015-0302-1

Swanberg, J. E., Clouser, J. M., Gan, W., Mannino, D. M., \& Flunker, J. C. (2015). Individual and occupational characteristics associated with respiratory symptoms among Latino horse farm workers. American J. Ind. Med., 58(6), 679-687. https://doi.org/10.1002/ajim.22452

Swanberg, J. E., Clouser, J. M., Gan, W., Flunker, J. C., Westneat, S., \& Browning, S. R. (2017). Poor safety climate, long work hours, and musculoskeletal discomfort among Latino horse farm workers. Arch. Environ. Occup. Health, 72(5), 264-271. https://doi.org/10.1080/19338244.2016.1216387

Swanberg, J. E., Clouser, J., Westneat, S., Marsh, M., \& Reed, D. (2013). Occupational injuries on thoroughbred horse farms: A description of Latino and non-Latino workers' experiences. Intl. $J$. Environ. Res. Public Health, 10(12), 6500-6516. https://doi.org/10.3390/ijerph10126500

Thomas, H. S. (2007). Bedding choices. The Horse (1 Dec. 2007). Lexington, KY: The Horse. Retrieved from http:/www.thehorse.com/articles/20156/bedding-choices

Tutluoğlu, B., Atis, Anakkaya, A. N., Altuğ, E., Tosun, G. A., \& Yaman, M. (2002). Sensitization to horse hair, symptoms and lung function in grooms. Clin. Exp. Allergy, 32(8), 1170-1173. https://doi.org/10.1046/j.1365-2745.2002.01439.x

USDA. (2015). Demographic characteristics of hired farmworkers and all wage and salary workers, 2012. Washington, DC: USDA Economic Researech Service. Retrieved from http://www.ers.usda.gov/topics/farm-economy/farm-labor/background.aspx

USDOL. (2005). National Agricultural Workers Survey (NAWS): Findings from NAWS 2001-2002: A demographic and employment profile of United States farm workers. Research Report No. 9. Washington, DC: U.S. Department of Labor.

USDOL. (2010). National Agricultural Workers Survey 2010. OMB No. 105-0453. Washington, DC: U.S. Department of Labor.

USHR. (2008). Hidden tragedy: Underreporting of workplace injuries and illnesses. Washington, DC: U.S. House of Representatives, Committee on Education and Labor.

Ware Jr., J. E., Kosinski, M., \& Keller, S. D. (1996). A 12-item short-form health survey: Construction of scales and preliminary tests of reliability and validity. Med. Care, 34(3), 220-233. https://doi.org/10.1097/00005650-199603000-00003

Westendorf, M., \& Krogmann, U. (2013). Horse manure management: Bedding use.Fact Sheet No. 537. New Brunswick, NJ: New Jersey Agricultural Experiment Station. Retrieved from https://esc.rutgers.edu/fact_sheet/horse-manure-management-bedding-use/

Winkelman, S., Chaney, E., \& Bethel, J. (2013). Stress, depression, and coping among Latino migrant and seasonal farmworkers. Intl. J. Environ. Res. Public. Health, 10(5), 1815-1830. https://doi.org/10.3390/ijerph10051815 